\title{
Hurricane Dennis' Impact on Cuban Agriculture ${ }^{1}$
}

\section{William A. Messina, Jr. and Thomas H. Spreen ${ }^{2}$ \\ General Information}

Between July 7 and July 9, 2005, Hurricane Dennis moved along the southern coast of Cuba then moved across the island, enveloping nearly the entire country with strong hurricane and tropical storm force winds and driving rain. This was the fourth major hurricane to strike Cuba in the last four years. As a Category 4 storm on the Saffir-Simpson Hurricane Scale when it came ashore in central Cuba on July 8, Hurricane Dennis brought with it sustained winds reported at nearly $150 \mathrm{mph}(240 \mathrm{kph})$ and wind gusts as high as $155 \mathrm{mph}$ (250 kph), making it the strongest hurricane to strike Cuba in four decades (Havana Journal, July 10, 2005). [For details on the Saffir-Simpson Hurricane Scale, go to the U.S. National Hurricane Center website at http://www.nhc.noaa.gov/aboutsshs.shtml.]

As Hurricane Dennis approached southeastern Cuba on July 7, the U.S. National Hurricane Center (NHC) reported that hurricane force winds extended outward for 50 miles from the center of the storm, while tropical storm force winds extended for up to 140 miles from the center. Prior to the eye of Hurricane Dennis making landfall in central Cuba, the storm traveled parallel to Cuba's shoreline south of the island, blanketing Cuba's eastern-most provinces with tropical storm force winds and very heavy rainfall, which the NHC reported could be as high as 5 to 10 inches and possibly as high as 15 inches over the Sierra Maestra mountains in southeastern Cuba. With Cuba experiencing severe drought conditions for the last few years, particularly in the eastern portions of the island, the rainfall associated with the storm allowed notable replenishment of some of the nation's water reservoirs and presumably helped to replenish groundwater resources. However, such heavy rainfall amounts over a short period of time caused serious flooding problems in many areas, including the destruction of an important road between Santiago de Cuba and Granma provinces in the Sierra Maestra Mountains. Prensa Latina (July 12, 2005a) reported that $20 \mathrm{~km}$ of Cuba's railway lines were destroyed by the storm.

Hurricanes tend to move across Cuba's long and relatively narrow land area. In the case of Hurricane Dennis, however, after moving parallel to Cuba's south coast just offshore, the eye of the hurricane moved onshore on the southern coast in the central portion of the island near the port city of Cienfuegos (Figure 1) at about 1PM on July 8. Once it made landfall, the storm traveled slowly west-northwest across a major portion of the island until it exited at

1. This is EDIS document FE570, a publication of the Department of Food and Resource Economics, Florida Cooperative Extension Service, Institute of Food and Agricultural Sciences, University of Florida, Gainesville, FL. Published August 2005. Please visit the EDIS website at http://edis.ifas.ufl.edu.

2. William A. Messina, Jr., Coordinator of Economic Analysis, and Thomas H. Spreen, Professor and Chair, Department of Food and Resource Economics, Florida Cooperative Extension Service, Institute of Food and Agricultural Sciences, University of Florida, Gainesville, FL.

The Institute of Food and Agricultural Sciences (IFAS) is an Equal Opportunity Institution authorized to provide research, educational information and other services only to individuals and institutions that function with non-discrimination with respect to race, creed, color, religion, age, disability, sex, sexual orientation, marital status, national origin, political opinions or affiliations. U.S. Department of Agriculture, Cooperative Extension Service, University of Florida, IFAS, Florida A. \& M. University Cooperative Extension Program, and Boards of County Commissioners Cooperating. Larry Arrington, Dean 
Guanabo, approximately $30 \mathrm{~km}$ east of the city of Havana as a Category 1 hurricane (Bauzá; July 9, 2005; Boadle, July 9, 2005). The eye of the storm was over land in Cuba for about 11 hours.

Because of its path, Hurricane Dennis directly and significantly impacted 12 of Cuba's 14 provinces (all but Cuba's western-most province Pinar del Rio and the Isle of Youth, off Cuba's southwest coast), affecting eight million of Cuba's total population of over 11 million (UN-OCHA, July 13, 2005).

The hurricane caused 16 deaths in $\mathrm{Cuba}^{3}$ the most of any storm since Hurricane Flora in 1963, which caused over 1,100 deaths and prompted a complete restructuring of Cuba's emergency preparedness systems, which now rank among the best in the developing world. ${ }^{4}$ Over 1.5 million Cubans were evacuated in advance of the storm, along with nearly 17,000 tourists (Reuters, 11 July 2005).

Initial estimates of economic damage from Hurricane Dennis are in excess of $\$ 1.4$ billion, although in a televised speech and program on July 11 and 12 Fidel Castro indicated that had the storm struck the city of Havana directly, damage could have exceeded $\$ 3$ billion (Oramas, July 12, 2005).

Storm assessment and recovery efforts have been hampered by severe damage to electrical and communications services across the island from Hurricane Dennis. These include the destruction of over 1,000 electrical power poles, 28 radio and communication relay towers, 4 television towers, and 39 high voltage electric towers by the storm's ferocious winds (Reuters, July 11, 2005; Prensa Latina, July 12, 2005a).

Initial reports indicated that more than 120,000 homes were damaged by the storm, 15,000 of which collapsed; 24,000 of which had their roofs blown off; 60,000 of which had partial roof damage; and 25,000 of which had other damage (UN-OCHA, July 13, 2005). Over 73,000 Cuban people were reported to be homeless and nearly 160,000 did not have adequate shelter as a result of damages caused by the storm (Havana Journal, July 11, 2005). Also reported was significant damage to schools, stores, and factories throughout the island along with 160 health facilities, including clinics, hospitals, and physicians offices.

Cuba's official newspaper Granma reported on July 12 that 2.5 million people (over 20 percent of the Cuban population) were without running water due to damage to water distribution systems, contamination of water supplies, and/or the lack of electrical power to run water pumps (Oramas, July 12, 2005). The affected areas were reportedly being served by water tankers until such time as their systems could be repaired, cleaned, or otherwise back in service.

\section{Agriculture}

Because of the communications disruptions caused by the storm, it has been particularly difficult to obtain detailed information from rural areas on the nature and extent of damage to Cuba's agricultural sector. Preliminary reports, however, indicate that the damage to agriculture throughout the central portions of the island was extensive, which would be consistent with the damage expected from a storm of this magnitude (UN-OCHA, July 13, 2005).

\section{Citrus}

The impact on Cuba's citrus industry is expected to be particularly significant, as the storm passed directly over some of Cuba's most important citrus producing areas, including the groves at Jagüey Grande, the largest contiguous planting of citrus trees in the world. In a broadcast speech by Cuban President Fidel Castro on July 11, he reported that "the entire crop of citrus fruits [in the region] was lost - 200,000 tonnes of grapefruit fell from the trees, as did 160,000 tonnes of oranges. At hundreds of dollars per tonne, that's a huge loss for our exports" (Mail \& Guardian Online, July 12, 2005). Separately, a Reuters news service report from Cuba indicated that the storm uprooted citrus trees and that most of the projected 250,000 metric tonne grapefruit harvest was knocked off the trees and lost in the groves in Jagüey Grande along with a similar volume of oranges anticipated for the 2006 crop (Frank, July 11, 2005). Other reports indicate losses to the citrus production could be as high as 360,000 metric tonnes (MT). 


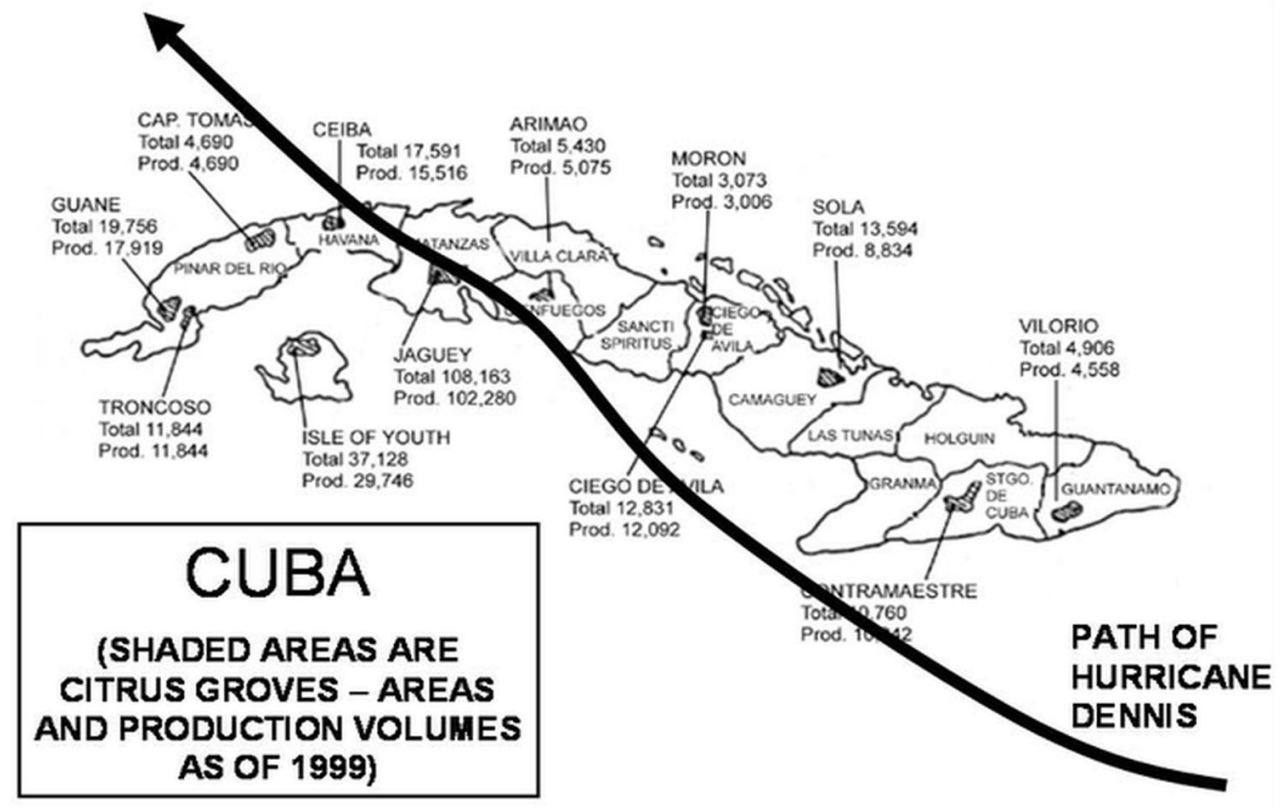

Figure 1. Path of Hurricane Dennis

Although the production area for citrus in Cuba has contracted in recent years, yields have increased substantially with production in 2002-03 estimated at nearly $800,000 \mathrm{MT}$. Of this total, approximately 480,000 MT were round oranges and 227,000 MT were grapefruit. Jagüey Grande accounts for approximately 50 percent of Cuba's total citrus production and about 75 percent of Cuba's citrus exports (Muraro, et al., 1998).

Cuba's grapefruit harvest typically begins in August, so the fruit was almost ripe when Hurricane Dennis struck, and therefore vulnerable to the high winds associated with the storm. Given the experience of the Indian River citrus producing region of east Florida with hurricanes in 2004, it is likely that nearly the entire grapefruit crop in the Jagüey Grande area was destroyed by Hurricane Dennis.

Nearly all of Cuba's round orange production is Valencia. Given the relative immature state of the Valencia crop, it is likely that Valencia production will be less affected relative to grapefruit, but the experience of Hurricane Charley in southwest Florida in 2004 suggests that a Category 4 hurricane will destroy 60 to 80 percent of the crop.
It is also likely that significant tree damage occurred. The peculiar nature of citrus production in Jagüey Grande may limit tree destruction. Most citrus production in this region occurs in rocky soils where dynamite has been used to create space for trees to be planted. With root systems well secured in the surrounding rocky soils, the trees are less prone to being blown over from high wind, although substantial limb damage likely occurred.

Prior to Hurricane Michelle striking Cuba in 2001, Cuba's citrus industry had been experiencing resurgence. Cuba's total citrus crop in the 2000-01 marketing year was estimated at 950,000 MT. In the absence of Hurricane Michelle, Cuba's grapefruit crop in the 2001-02 season would likely have been about 350,000 MT (Spreen, Brown, and Messina, 2001). With Hurricane Michelle, Cuba's 2001-02 citrus crop was 477,000 MT and the 2002-03 crop was near 800,000 MT. Data are unavailable on the 2003-04 crop.

With extensive damage to Florida's 2004-05 grapefruit crop from hurricanes, Cuba has been enjoying record high prices for its grapefruit. Cuba ranks third in world grapefruit production, following the United States and Israel. Nearly all of Cuba's grapefruit production is processed into juice. Although exact production figures are unavailable, it 
is likely that Cuba is the second largest grapefruit juice producing country in the world, following the United States. With the likelihood that grapefruit production in Florida will realize some "hangover" effect from the hurricanes of 2004, extensive damage to Cuba's grapefruit crop will add to the likelihood of high prices for grapefruit juice in the world market.

The extent of the damage to Cuba's largest citrus juice processing facility, which is located in Jagüey Grande (and operated as a joint venture between the Cuban government and a Panamanian company with Israeli principals), was unknown at the time of publishing this report. Hurricane force winds undoubtedly struck the facility, given the path of the storm, which suggests that the processing plant likely sustained significant damage, as was the case when hurricane Michelle struck the same area of Cuba in 2001. While it was too early in the season for the processing plant to have been very active, damages may constrain processing fruit juices in the near term, although there are other juice processing plants on the island. Three new processing facilities have opened in Cuba over the past five years, one each at the extreme eastern and western end of the island and a third plant located in central Cuba.

\section{Sugar}

Sugarcane crops generally are able to largely withstand heavy winds and rains associated with hurricanes with minimal damage, although "lodging" of the cane from heavy winds and rains can create problems at harvest. Reuters news service (Frank, July 15, 2005) reported damage at a number of sugar mills but, interestingly, noted that "damage to the [sugar] industry appeared balanced by much needed moisture across most of the country." However, sugar is a far less important crop for Cuba now than it was in the late 1980s. The harvest for the 2004-05 season is reported to be around 1.3 million metric tons, which is only about 15 percent of the production levels of the late 1980s and the lowest production volume for Cuba in nearly 100 years.

\section{Other Crops}

Coffee plantations in the mountains in eastern and central Cuba reportedly were hit hard, with much damage from winds and flooding (Frank, July 15,
2005). Mango and papaya crops also suffered considerable damage, along with grain and cabbage crops and irrigation systems (UN-OCHA, July 13, 2005). One report indicated that 30,000 acres of bananas were destroyed by the storm (Bauzá and Baro Diaz, July 13, 2005). Another report indicated that 127,000 tons of vegetables also were lost, along with large volumes of other fruits and tubers (Prensa Latina, July 12, 2005a).

Reports also indicate that 27 greenhouse structures for the propagation of vegetables for domestic consumption were damaged or destroyed by the storm (Prensa Latina, July 12, 2005a). However, in Matanzas Province, it is reported that 40 lightweight vegetable propagation structures erected by German Agro Action (one of Germany's largest private organizations working in the area of development cooperation and humanitarian aid) were dismantled and stored in advance of the hurricane and have since been rebuilt and are once again in production (Deutsche Welthungerhilfe).

\section{Livestock}

Nearly 500,000 animals and livestock were reportedly moved into protective shelters prior to the storm (AIN, July 10, 2005). Despite these preparations, Cuba's official newspaper Granma reported that 73,000 head of poultry were destroyed by the storm (Oramas, July 12, 2005). As has been the case in prior hurricanes, damage to barns, dairy milking parlors, and other structures undoubtedly was significant, particularly in the areas over which the eye of the storm passed.

\section{Food Supplies}

Feeding the Cuban people continues to be a difficult challenge for the government and this storm certainly will not help that situation, as Hurricane Dennis also was reported to have ruined approximately 3,000 tons of stored food (Prensa Latina, July 12, 2005a).

The United Nations Office for the Coordination of Humanitarian Affairs reports that:

Damages to agriculture and the food industry have been very heavy in all the affected 12 provinces of Cuba, mainly fruit, vegetables, 
and edible roots. Urban agriculture, a very significant agricultural production system supplying populated areas, has sustained heavy damages. Cienfuegos and Granma provinces are reporting the loss of 27,000 hectares of the most diverse agricultural crops, a figure very close to the total planted areas. The storm also destroyed agricultural storage facilities, structures for farm animals, egg farms, and other agribusiness installations. It must be noted that these are very partial figures. As reports come in from other provinces, the whole picture will be more evident, showing devastating losses in agriculture, including animal husbandry, and food production and processing units (UN-OCHA, July 13, 2005, page 2).

Separately, it was reported that Fidel Castro stated that $\$ 400$ million in additional investment will be provided for foodstuffs to help feed the population (Oramas, July 12, 2005) and that 220,000 tons of food for those affected by the hurricane were to be distributed (Prensa Latina, July 12, 2005b).

\section{Other Economic Sectors}

While Cuba's infrastructure suffered significant damage from the storm, other important commercial and industry sectors of Cuba's economy beyond agriculture are reported to have sustained only limited damage. Other than having to cease operations during the hurricane, Reuters news service reported that Cuba's nickel and oil industries were largely spared from damage (Frank, July 11, 2005).

The tourist industry is particularly important to the Cuban economy at this time because it is Cuba's primary source of hard-currency, foreign-exchange earnings. A quick review of the damage to Cuba's tourist sector from Hurricane Dennis is therefore in order as it may have important implications for Cuba's future economic prospects, and perhaps for purchases of food and agricultural products from the United States, which must be made in cash. Frank (July 15, 2005) writes that the Cuban government may be forced to almost double food imports as a result of damage caused by the storm.
High winds, heavy rains, and coastal flooding from Hurricane Dennis reportedly caused significant damage to a number of tourist facilities along the southern coast and coastal islands of Cuba. However, the majority of Cuba's tourism is located along the northern coast and in the city of Havana. Cuba's official newspaper Granma reported that 21 hotels were damaged by the hurricane, although it did not provide any details on the location of these hotels or the extent of the damage (Oramas, July 12, 2005). Given the path of the storm, Cuba's tourist beach resort area at Varadero almost certainly faced hurricane force or near hurricane force winds and heavy rains. However, it has been reported that this area and other tourist areas further east along the north coast of the island were spared the heaviest impacts of the storm and experienced limited damage, so the effect on Cuba's tourist sector does not appear to be particularly significant (Frank, July 11, 2005).

The United States and the European Union both offered economic aid to Cuba, but Cuban President Fidel Castro declined, accepting instead aid and assistance from Venezuela (AIN, July 12, 2005).

The United Nations World Food Program (UN/WFP) recently announced an Immediate Response Account Emergency Operation to assist particularly vulnerable groups in Cuba (specifically pregnant and nursing women, children under five years of age, and the elderly) affected by Hurricane Dennis. This operation will assist about 111,000 people with the delivery of food supplies at a total cost of about $\$ 490,000$. The UN/WFP also announced a three-month Emergency Operation for Cuba to provide assistance to an additional 773,000 members of these same vulnerable groups who have been affected by the drought through the provision of supplemental food rations of rice, beans, and vegetable oils at a cost of over $\$ 3.7$ million (World Food Programme).

While Hurricane Emily also paralleled the south coast of Cuba only about 10 days after Hurricane Dennis, it was a compact storm and passed far enough south of the island so that Cuba did not experience any significant winds from this storm. However, Cuba did experience some rain from Hurricane Emily that was locally heavy in some areas, particularly in the 
southwestern portions of the island and on the Isle of Youth where some coastal flooding is reported to have occurred (Prensa Latina, July 18, 2005).

\section{References}

AIN. July 10, 2005. Cuba Begins Recovery as Gulf States Await Dennis. Agencia de Información Nacional. Division of the Cuban National News Agency, Havana, Cuba. http://www.ain.cubaweb.cu.

AIN. July 12, 2005. Venezuelan Experts Dispatched to Cuba and Jamaica. Agencia de Información Nacional. Division of the Cuban National News Agency, Havana, Cuba. http://www.ain.cubaweb.cu.

Bauzá, Vanessa. July 9, 2005. 10 Dead as Dennis Pummels Cuba. Ft. Lauderdale Sun Sentinel, Fort Lauderdale, FL. http://www.sun-sentinel.com.

Bauzá, Vanessa, and Madeline Baro Diaz. July 13, 2005. Cuba Tallies up Dennis' Toll:16 Dead and \$1.4 Billion in Damage. Ft. Lauderdale Sun Sentinel, Fort Lauderdale, FL. http://www.sun-sentinel.com.

Boadle, Anthony. July 9, 2005. Update 1-Hurricane Dennis Hits Havana, 32 Dead in Caribbean. Reuters News Service Online. http://today.reuters.com/news/.

Deutsche Welthungerhilfe. 2005. Aid for hurricane victims on (sic) Cuba. German Agro Action. Bonn, Germany. http://www.welthungerhilfe.de/WHHEN/projects/ 03latinamerica/ Aid_for_hurricane_victims_on_Cuba_html.

Frank, Marc. July 11, 2005. Cuba Counts up Damage in Wake of Hurricane Dennis. Reuters News Service Online. http://today.reuters.com/news/.

Frank, Marc. July 15, 2005. Cuba's Crumbling Infrastructure Taxes Residents Patience. Financial Times Online. http://news.ft.com/home/us.

Havana Journal. July 11, 2005. Hurricane Damage Statistics in Cuba. http://havanajournal.com/politics_comments/ 3575_0_5_0_C/.
Havana Journal. July 10, 2005. Update after Hurricane Dennis Hits Cuba. http://havanajournal.com/politics_comments/ 3570_0_3_0_C/.

Mail \& Guardian Online. 12 July, 2005. Hurricane Death Toll Mounts as Cuba Refuses Aid. http://www.mg.co.za/.

Muraro, Ronald P., Thomas H. Spreen, and Armando Nova Gonzalez. 1998. Cuban Citrus Industry's Transition into the International Free Market Arena. Proceedings of the Florida State Horticultural Society 111: 169-73.

Oramas, Joaquin. July 12, 2005. Damage from Dennis at \$1.4 Billion. Granma Digital Internacional, Havana, Cuba. http://www.granma.cu.

Prensa Latina. July 18, 2005. Emily Lashes Yucatan Peninsula. Latin American News Agency, Havana, Cuba. http://www.plenglish.com/.

Prensa Latina. July 12, 2005a. Cuba Suffers \$1.4 Billion in Hurricane Losses. Latin American News Agency, Havana, Cuba. http://www.plenglish.com/.

Prensa Latina. July 12, 2005b. Fidel Castro Tallies Hurricane Damage, Sixteen Dead. Latin American News Agency, Havana, Cuba. http://www.plenglish.com/.

Reuters Online. July 11, 2005. Hurricane Dennis Killed 16 in Cuba. http://today.reuters.com/news/.

Spreen, Thomas H., Mark G. Brown, and William A. Messina, Jr. 2001. The Potential Impact of Hurricane Michelle on the Cuban Citrus Industry. Electronic Data Information Source (EDIS) FE328. Department of Food and Resource Economics, University of Florida, Gainesville, FL. http://edis.ifas.ufl.edu/FE328.

UN-OCHA. 13 July, 2005. Caribbean: Hurricane Dennis OCHA Situation Report No. 7. United Nations Office for the Coordination of Humanitarian Affairs, New York, NY. http://www.reliefweb.int/rw/dbc.nsf/ doc100?OpenForm. 
U.S. National Hurricane Center. July 8, 2005.

Update on Hurricane Dennis. NOAA, Miami, FL. http://www.nhc.noaa.gov/.

World Food Programme. 12 August 2005. World

Food Programme Emergency Report 2005. UN

World Food Programme Report No. 33/2005, United

Nations, New York, NY.

http://www.reliefweb.int/library/documents/2005/

wfp-emergency-12aug.pdf.

\section{Additional Notes:}

3. Thirteen deaths were reported in Granma province and two in Santiago de Cuba, both in eastern Cuba, and one death was reported in Sancti Spiritus province in central Cuba.

4. A Reuters news service article (July 12, 2005a) reported that 10 major hurricanes hit Cuba between 1985 and 2004 but they caused only 22 deaths in total. 